\title{
Duyuların Gelişimi ve Duyu Bütünleme
}

\section{Sensory Development and Sensory Integration}

\author{
Kadriye Özyazıc1 ${ }^{1 *}$, Ebru Boğa Baran², Nurcan Alagöz ${ }^{3}$, Kübranur Varlıklıöz ${ }^{4}$, Zekeriya \\ Arslan $^{5}$, Semra Akto ${ }^{6}$, Mehmet Sağlam ${ }^{7}$ \\ ${ }^{1}$ Öğr. Gör., Sivas Cumhuriyet Üniversitesi, kozyazici@cumhuriyet.edu.tr, 0000-0003-2559-5816, *Sorumlu \\ Yazar \\ ${ }^{2}$ Öğr. Gör., Dicle Üniversitesi, ebru.boga@dicle.edu.tr, orcid.org/0000-0001-9487-6123 \\ ${ }^{3}$ Öğr. Gör., Bingöl Üniversitesi, nalagoz@bingol.edu.tr, orcid.org/0000-0002-1344-6760 \\ ${ }^{4}$ Öğr. Gör., Ondokuz Mayıs Üniversitesi, kubranur.varliklioz@omu.edu.tr, orcid.org/0000-0002-1811-4220 \\ ${ }^{5}$ Öğr. Gör., Kahramanmaraş Sütçü İmam Üniversitesi, z.arslan@ksu.edu.tr, orcid.org/0000-0001-8861-0310 \\ ${ }^{6}$ Öğr. Gör., Mardin Artuklu Üniversitesi, semraakto@artuklu.edu.tr, orcid.org/0000-0002-0185-1339 \\ ${ }^{7}$ Dr. Öğr. Üyesi, İnönü Üniversitesi, mehmet.saglam@inonu.edu.tr, orcid.org/0000-0003-1784-4472
}

Geliş tarihi/Received : 13.02.2021 Kabul tarihi/Accepted: 12.08.2021 Yayın tarihi/Published: 30.12.2021

\begin{abstract}
ÖZET
Anne karnındayken gelişmeye başlayan duyular, çevreyle etkileşim kurmada ilk aracılar olarak değerlendirilmektedir. Bu aracıların sağlıklı gelişimi ve birbirleri uyumlu bir şekilde kullanımı gelişim sürecinde son derece önemlidir. Duyusal uyaranlara doğru uyaranlar ile karşılık verilmesi ve duyusal organizasyonun yapılması beklenen bir durum iken bazen bu durumun sağlanmadığı bilinmektedir. Duyu bütünleme sürecinin sağlıklı işlemesi anne karnından başlayarak duyuların gelişim seyri ve doğum sonrası süreçte desteklenmesinden etkilenmektedir. Ancak atipik gelişimsel süreçlerde duyu bütünleme işleminde problemler ortaya çıkmaktadır. Duyu bütünleme sürecinde ortaya çıkan problemlerin giderilmesinde profesyonel destek sağlanması kadar ebeveynlerin bu konudaki farkındalıklarının yüksek olması önemlidir. İster tipik ister atipik gelişim süreci olsun, ebeveynlerin bu konudaki hassasiyeti hem gelişim sürecini desteklemekte hem de erken tanıya ve erken müdahaleye zemin hazırlamaktadır. Duyusal gelişimin ve duyu bütünlemenin gelişim süreci içerisindeki önemi dikkate alınarak bu çalışmada; duyusal sistemlerin oluşumu ve gelişimi, duyu bütünleme çalışmaları ve duyusal gelişimin desteklenmesi ele alınmıştır.
\end{abstract}

Anahtar Kelimeler: Duyu, duyuların gelişimi, duyu bütünleme

\begin{abstract}
The senses that begin to develop in the womb are considered as the first mediators in interacting with the environment. The healthy development of these mediators and their use in harmony with each other are extremely important in the development process. While it is expected to respond to sensory stimuli with the right stimuli and to make sensory organization, it is known that sometimes this situation is not achieved. The healthy functioning of the sensory integration process is affected by the development of the senses starting from the mother's womb and their support in the postnatal period. However, problems arise in the sensory integration process in atypical developmental processes. It is important for parents to be aware of this issue as much as providing professional support in eliminating the problems that arise in the sensory integration process. Whether it is a typical or atypical developmental process, the sensitivity of parents in this regard both supports the development process and lays the groundwork for early diagnosis and early intervention. Considering the importance of sensory development and sensory integration in the development process, in this study; formation and development of sensory systems, sensory integration studies and support of sensory development are discussed.
\end{abstract}

Key Words: Sensory, development of the senses, sensory integration 


\section{GíRiș}

Anne karnındayken gelişmeye başlayan duyular, çevreyle etkileşim kurmada ilk aracılar olarak değerlendirilmektedir. Henüz gebeliğin üçüncü haftasında amniyon sıvısının basınç ve sıcaklığını hisseden bebek, 1sı ve dokunmaya yönelik ilk somatik duyu deneyimlerini yaşamaktadır. Duyusal uyaranlara verilen ilk cevaplar, döllenmeden yaklaşık beş hafta sonra meydana gelmektedir (Pekçetin, 2015). Duyu, çevreden gelen verilerin göz, kulak, dil, burun ve deri gibi duyular ile karşılıklı etkileşime girmesi sonucu ortaya çıkmaktadır. Duyular ile birlikte yaşam anlamlı, hareketli ve renkli hale gelmektedir (Mather, 2018). Çevreye adapte olmayı da kolaylaştıran duyular, yaşamın devam ettirilmesinde önemli bir rol oynamaktadır (Çetin Sultanoğlu ve Aral, 2015). Öğrenmek, istekleri yerine getirmek ve bundan haz duymak, öz-kontrol sahibi olmak, motor beceriler ve üst düzey bilişsel işlevler geliştirmek için duyular kullanılmaktadır (Kranowitz, 2006).

Duyuların işlenmesi, organize edilmesi, yorumlanabilmesi, çevreye uygun şekilde yanıt verebilmesi, yani duyusal girdilerin düzenlenmesi "duyusal bütünleme" kavramı ile açıklanmaktadır (Magalhães, 2008; Cabral Silva ve Tudella Martinez, 2015). Literatürde "duyusal işlemleme", "duyu bütünlüğü" gibi kavramlarla da yer alan duyusal bütünleme; anlamlı ve amaçlı davranışlar oluşturabilmek için çevreden duyular aracılığıyla alınan bilgilerin organize edilmesini ve yorumlanmasını sağlayan nörolojik gelişim sürecini ifade etmektedir (Schaaf ve Miller, 2005). İlk olarak 1963 yılında Ayres tarafından geliştirilen duyu bütünleme teorisi, karmaşık aktivitelerin temeli olarak değerlendirilmektedir (akt. Dunn, 2001). Sağlıklı bir duyusal bütünleme süreci yaşamayan çocuklar, günlük yaşamsal aktivitelere katılmada ve günlük yaşam becerilerini kazanmada gecikmeler yaşayabilmektedir ve bu gecikmeler, gelişimsel açıdan da geriliğe ve yetersizliğe yol açabilmektedir (Armstrong, Redman-Bentley ve Wardell, 2013; Bar-Shalita, Parush ve Vatine, 2008). Dolayısıyla, tipik bir gelişim gösteren ve normal seyirde devam eden nöro-gelişimsel süreçte, duyusal girdilerin doğru bir şekilde işlenmesi oldukça önemli görülmektedir (Çelik, Elbasan, Gücüyener, Kayıhan ve Huri, 2018).

Duyusal bütünleme, çevreden gelen uyaranların ve deneyimlerin beyinde işlenme süreci sonunda ortaya çıkan motor davranışları, duygu ve dikkat gibi tepkileri ifade etmektedir. Bir erken müdahale yöntemi olarak da değerlendirilen duyu bütünleme genel olarak beş temel ilke doğrultusunda açıklanmaktadır:

1. Duyu bütünleme ve duyu-motor gelişim öğrenme için oldukça önemli ve gerekli bir beceridir.

2. Çevresel etkenler ve etkileşimler beyin gelişimini desteklemede önemli bir rol oynamaktadir.

3. Merkezi sinir sistemi değişime ve gelişime açıtır.

4. Anlamlı duyu-motor faaliyetleri, diş çevreden gelen uyaranların sonucu olarak sinir sisteminde meydana gelen davranışların yanı sıra öğrenme sürecinde uyarılan nöral değişimleri de desteklemektedir.

5. Duyusal gelişimde belirli bir sıra vardır ve her bir gelişim basamağı bir sonraki duyusal gelişim süreci için zemin oluşturmaktadır. Duyusal gelişim ise yaşam boyu devam etmektedir (Miller, Anzalone, Lane, Cermak ve Osten, 2007).

Beyin gelişimi sürecinde sinaptik bağlantıların yoğunlaşması için sadece genetik faktörler yeterli görülmemektedir. Bu süreçte çevresel faktörler de devreye girerek çift yönlü bir etkileşim gerçekleştirmektedir. Optimal beyin fonksiyonu için duyusal girdiler ve duyular aracılığıyla algılanan çevresel bilgiler oldukça önemli bir rol oynamaktadır. Nitekim, özellikle 
gelişimin kritik dönemlerinde, yeterli ya da uygun miktarda duyusal veriler olmadığ zaman beyin gelişiminde anormallikler ve davranış problemleri oluşabilmektedir. Ayrıca duyusal veriler, tek bir duyu ile değil, diğer duyularla bütün olarak işlenmektedir ve kompleks bir süreç olarak kabul edilmektedir (Sidar ve Öztop, 2017). Duyusal deneyimlerden yoksun kalmak; önemli ve kalıcı bilişsel, sosyal ve duygusal işlev bozukluklarına sebep olabilmektedir. İyi düzenlenmiş zengin ve uyarıcı bir çevre ile kendi başına aktivite başlatan ve devam ettiren çocuklar; dikkat becerilerini geliştirerek ve etkileşimler kurarak duyusal açıdan da sağlıklı bir gelişim süreci yaşamaktadır (Balıkçı, 2013).

Prenetal dönemde başlayan duyu gelişimi, bebeklerin doğumdan itibaren yaşayacağ uyum sağlayabilmeleri ve hayatta kalabilmeleri için anne karnında büyük oranda tamamlanmaktadır. Bebekler, doğdukları andan itibaren çevrelerine büyük ilgi duymakla birlikte yüksek bir öğrenme potansiyeline sahiptirler. Bu nedenle gelişimin en hızlı olduğu bebeklik döneminden itibaren gelişimini sağlanmasında duyular son derece önemlidir.

\section{DUYUSAL SISTEMIN SINIFLANDIRILMASI}

İnsanlarda her ne kadar beş duyunun varlığından bahsedilse de duyusal sistemin sinıflandırılmasında vestibüler duyu (denge ve hareket duyusu), proprioseptif duyu (derin duyu), taktil duyusu (dokunma duyusu), tat duyusu, koku duyusu, görme duyusu, işitme duyusu olmak üzere yedi farklı sistem şeklinde ele alınır.

\subsection{Vestibüler Duyu}

Vestibüler duyu, bireye vücudu ve başının nerede olduğu ile ilgili evrendeki ilişkisi hakkında bilgi veren bir duyudur. Çocukların hareketi ve etrafındaki nesnelerin hareketleri ile o nesnelerin vücuduyla ilişkisinin ne yönde olduğu hakkında bilgiler vestibüler duyuyla farkedilir. Vestibüler sistem birleştirici bir sistem olup, bireyin yer çekimi ve dünya ile ilişkisini belirler (Taygur Altıntaş ve Yılmazer, 2015). Vestibüler sistem birçok yönden diğer duyulardan farklı olup günlük yaşamda önemli bir rolü vardır. Çünkü reflekslerden en yüksek algılama ve bilinç düzeylerine kadar değişen şaşırtıcı bir işlev yelpazesine sahiptir (Angelaki ve Cullen, 2008). Vestibüler sistem, dengeyi sağlayan, dünyanın yerçekimi alanına göre normal oryantasyonunu koruyan birincil duyu sistemidir. Hızlanmada, yavaşlamada ya da eğilmelerde de bu denge muhafaza edilir. Vestibüler sistem, başın pozisyonuna veya hareketine göre gözlerin, boynun, gövdenin ve uzuvların pozisyonunu korumaktan sorumludur (Lahunta ve Glass, 2009).

Duyusal reseptörlerinin dejenerasyonu nedeniyle iç kulak ve iç kulaktaki semisirküler kanallar zarar görür. Bu durumdan vestibüler sistem de etkilenerek baş pozisyonu ve hareketlerinde birtakım bozulmalar ortaya çıkar. Görsel ve alt ekstremitelerde girdi azalınca dengeyi vestibüler kontrol eder. Sağlıklı yetişkinde görsel ve destek yüzeyi ile ilgili bilgi olmasa dahi denge sağlanabilir fakat normal sınırlarda vestibüler sistem bozulması durumunda yaşlılar dengelerini kaybederek düşebilirler (Fırat, 2019). Doğum sonrasında ise eğer vestibüler sistemde bozulmalar yaşanırsa bunun etkisi yaşamının ilerleyen dönemlerinde çocuğu daha da güçsüzleştirir. Ayrıca yetişkinlerin aksine, vestibüler disfonksiyonu olan çocuklar doğumdan sonra veya kısa bir süre sonra eğer iyileştirici müdahaleler olmadıysa işlevlerini yerine getirmezler (Rine ve Wiener-Vacher, 2013).

Vestibüler sistem ile görsel bilgilerin uyuşmaması hareketle ile ilgili hastalıklara, baş dönmesi, mide bulantısı, yönelimin bozulması (vertigo gibi) vb. hislere neden olur (Arıhan, 2018). Bu gibi vestibüler fonksiyon kayıpları ya da bozulmaları söz konusu ise birtakım beyin kabuğu ile ilgili telafi edici süreçlerin, iyileşme için önemli olabileceği de belirtilmektedir (Cutfield, Scott, Waldman, Sharp ve Bronstein, 2014). Vertigo ve baş dönmesi gibi problemlerin çocuklukta çok yaygın olmadığı söylense de günümüzde artık daha sık rastlanıldığı da görülmektedir. 
Çocukluk döneminde en sık rastlanılan rahatsızlıklar orta kulak enfeksiyonu (otitis media) ve efüzyonu olup çocuklarda da bu problemlerin semptomlarına neden olmaktadır. Golz ve arkadaşlarının yaptığı çalışma, küçük yaşlardaki çocuklarda sıklıkla karşılaşılan denge ile ilgili problemlerin kronik orta kulak enfeksiyonundan kaynaklanabileceğini ve bu semptomların orta kulağın efüzyonu ve ventilasyonu boşaltıldıktan sonra düzeleceğini göstermiştir (Golz, Netzer, Yeger, Westerman, Gilbert ve Joachims, 1998). Ayrıca çocukların görme ve vestibüler sistemle ilgili yaşadıkları problemler, okuldaki performansları üzerinde de önemli bir etkiye sahip olabilir. Görsel yorgunluklar, baş ağrısı, baş dönmesi ve yakın görsel çalışmayla ilgili zorluklar, çocuklarda akademik başarıları zayıflatıcı olabilmektedir (Christina, Stephen, Douglas, Eileen, Julia, Podolak ve Grady, 2018).

Çöpkes (2013) yaptığı deneysel araştırmasında 3-10 yaş aralığında 26 otistik çocuk üzerinde vestibüler eğitimin duyu profili üzerindeki etkisini incelemiştir ve eğitimin etkisi tam olarak belirlenemeyip otizmli çocukların kişisel özellikleri dikkate alınarak eğitimin gerçekleştirilmesi gerektiği ortaya çıkmıştır). Çelik ve arkadaşlarının (2018) 10-12 ay arasındaki preterm ve term bebeklerin duyusal işlemleme becerilerini karşılaştırdıkları çalışmada preterm bebeklerin vestibüler işlemleme düzeylerinin term bebeklerden daha düşük olduğu ve erken dönemdeki gelişimsel değerlendirmelerde duyusal işlemleme becerilerinin dikkate alınması gerektiği saptanmıştır. Turhan (2018) 4-17 yaş arasındaki spastik diplejik serebral palsili çocuklarda duyu bütünleme tedavisinin; spastisite, denge ve motor fonksiyona etkisini araştırdığ 1 araştırmada duyu bütünleme tedavisinin tedavi programlarına eklenmesinin dengeyi iyileştirmede ve fonksiyonel bağımsızlığı arttırmada etkili olduğu sonucunu bulmuştur. Şeker (2019) 7-10 yaş arasındaki entelektüel yetersizliği olan çocukların denge becerileri üzerinde denge becerilerini geliştirmeye yönelik özel hareket eğitimi programının etkisini incelediği çalışmasında bu programın çocukların denge becerilerini geliştirdiğini belirlemiştir. Martens ve arkadaşları (2019) işitme kaybı olan tüm çocuklar için standart bir vestibüler taramanın çocukların motor, bilişsel ve psikososyal gelişimi üzerindeki etkilerini inceledikleri çalışmalarında bu taramanın vestibüler eksiklikleri farketmeyi, vestibüler disfonksiyonu gelişmekte olan çocuklar üzerinde yaşam kalitelerini iyileştirebilmede olumlu etkisi olduğunu belirtmişlerdir. Hoeve (2020) kolik ve kolik olmayan bebeklerdeki vestibüler düzensizliği araştırdığı araştırmasında kolik bebeklerin sadece çok ağlayan bebekler olmadığı ayrıca vestibüler düzensizliklerinin olduğu ve vestibüler hiperaktiviteyi azaltmak için tedavi yöntemlerine ihtiyaç olduğunu belirtmiştir.

\subsection{Proprioseptif Duyu}

Kas, eklem ve tendonlarda mekanoreseptörler bulunur. Bu mekanoreseptörlerin değişen pozisyon ve durumları algılaması ile proprioseptif sistem devreye girer ve vücut ile uzuvlarının konumunun beyin tarafindan algılanmasına yardımcı olur (Fidan, Yıldız ve Şahan, 2019).

Derin doku duyusu veya diğer bir adıyla beden farkındalığı duyusu olarak da bilinen proprioseptif duyu; gücü, yönü ve hareketi sağlayan duyusal mesajları ifade etmektedir. $\mathrm{Bu}$ duyuya ait reseptörler (proprioseptörler) kas ve eklemlerde yer almaktadır ve vücut pozisyonu ile ilgili bilgi sağlar. Vücudun bölümlerinin birbiri ve boşluktaki uyumunu sağlar, kasların ne kadar kasılacağını belirler, hareketin gerçeklemesi için gereken hız ve uygun zamanı da proprioseptif duyu belirlemektedir (Çetin Sultanoğlu ve Aral, 2015). Propriosepsiyon duyu reseptörleri için genellikle 'kas ve eklemlerde yer alan bir uyarıcı' tanımı yapılsa da, vücutta birçok proprioseptör bulunmaktadır ve sadece kas hassasiyetiyle ilgilenmezler. Örneğin akciğer ve bağırsaklardaki arterlerin şişkinliğini gösteren reseptörler de vardır. Proprioseptörler terimi uzuv duyularını içeren duyularla ilgilidir, bunlar; konum ve hareket, gerginlik ve kuvvet hissi, çaba ve denge duygusudur (Proske ve Gandevia, 2012). Kas iğcikleri, eklem reseptörlerine göre daha iyi anlaşılmıştır ve bağ dokusu ile çevrelenen dört ila sekiz adet özel kas lifinden oluşmuştur. Kaba hareketleri sağlayan büyük kaslar daha az kas iğciği bulundururken, el-göz 
gibi organların etrafinı saran kaslar gibi ince ve daha keskin hareket eden kaslar ise bu kas iğcikleriyle daha zengin bir biçimde desteklenmektedir (Arıhan, 2018). Bu tanımlardan da anlaşılacağı üzere eklem, organ, uzuv ve organellerin sağlı̆̆ını koruyarak, yaralanmalara engel olmada bu duyunun önemi büyüktür (Kaynak, Altun, Özer ve Akseki, 2015).

Çocuklarda proprioseptif yetenekteki gelişimsel değişikliklerin yaklaşık sekiz yaşlarında artık daha istikrarlı olduğunu söyleyen çalışmalar olsa da bu yetenek çocukluk boyunca ve ergenlikte de gelişmeye devam eder (Blecher, Heinemann, Assaraf, Konstantin, Chapman, Cope, Bewick, Banks, Zelzer, 2018; Goble, Lewis, Hurvitz ve Brown, 2005). Proprioseptif duyunun ayırt edilmesiyle ilgili yapılan bir çalışmada 4 ila 13 yaşları arasında proprioseptif duyunun doğrusal bir artış gösterdiği görülmüştür. Hatta parmak ucu pozisyonundayken karşı kolun aynı parmağıyla eşleştirme yapma çalışmalarındaki pozisyon doğruluğunun 24 yaşına kadar hâlâ iyileşmeye devam ettiği de görülmüştür (Goble ve vd., 2005).

Aman, Elangovan, Yeh ve Konczak (2015) proprioseptif duyu eğitiminin bozulmuş motor fonksiyonları iyileştirebilmek için uygulanabilecek bir davranışsal terapi olduğu sonucuna ulaşmışlardır. Bu çalışma ile duyu eğitimin ne kadar etkili olduğu, proprioseptif eğitimin somatosensoriyel ve sensorimotor fonksiyonda anlamlı gelişimler sağlayabildiğini, özellikle kortikal fonksiyonlardaki düzelmeyi sağladığı konusunda güçlü kanıtlar elde ettiklerini belirtmişlerdir. Kesavan, Frank, Cordero, Benharash ve Harper (2016) propripseptör liflere yerleştirilen titreşim cihazlarının prematüre bebeklerde yaygın olan uyku apnesinin engellenmesindeki etkisini inceledikleri çalışmalarında bebeklerde bu müdahale ile daha az solunum duraklamasının meydana geldiğini ve anormal solunum alma duraklarının azaldığını saptamışlardır. Özakın (2018) 5-10 yaş arasındaki otizmli çocuklarda duyu bütünleme eğitiminin propriosepsiyon duyu, motor performans ve duyu profili üzerine etkisini incelediği çalışmasında eğitimin olumlu yönde çok yönlü etkilere neden olduğu sonucunu bulmuştur. Chinn, Hoffmann, Leed ve Lockman (2019) 7-21 aylık bebeklerin vücutlarını nasıl konumlandırmaya başladıkları ve bunu yaparken de hangi motor stratejileri kullandıklarını inceledikleri çalışmalarında bebeklerin kullandıkları stratejilerin yaşla birlikte artış gösterdiğini, görme ve uzanma arasındaki eşgüdümün yaşla birlikte daha da arttığını yani duyular arasındaki koordinasyonun yaşla beraber artış gösterdiği sonucuna ulaşmışlardır.

\subsection{Taktil Duyu}

Dokunma, en temel ve ilkel iletişim biçimi olarak kabul edilmektedir (Mercuri, Stack, Trojan, Giusti, Morandi, Mantis ve Montirosso, 2019). Yaşamın ilk hisleri dokunsaldır. Prenatal dönemde dokunma duyusunun gelişimi görme ve işitme duyularına göre çok açık bir önceliğe sahiptir. Kutanöz ve trigeminal somatosensoriyel reseptörler, gebeliğin yaklaşık 4-7. haftalarında olgunlaşır. Gebeliğin yedinci haftasında, cenin dudaklarına dokunulduğunda hareket edebildiği ve 12 . haftada kavrama refleks tepkileri sergileyebildikleri bildirilmektedir (Bremner ve Spence, 2017). Gebeliğin erken dönemlerinde, embriyo dokunsal uyarımı algılayabilir ve dokunsal uyarıma yanıt verebilir. Annenin karın duvarı yoluyla rahimde dokunsal uyarımları fark edebilir (Castiello, Becchio, Zoia, Nelini, Sartori, Blason ve Gallese, 2010).

Bebek, doğum sırasında ve doğumdan hemen sonra sadece birkaç dakikadır hayatta olmasına rağmen dokunsal uyarıları alabilir (Castiello ve vd., 2010). Fetalden neonatal hayata geçiş, en dinamik ve hassas yaşam olaylarından biridir. Doğum ve doğumu takip eden zaman dilimi, bebek için psiko-fizyolojik olarak hassas bir dönemi temsil etmektedir. Bebeğin doğum travması yaşadığı bu anlarda, dokunsal uyarı ve fiziksel temas ile rahim dışındaki hayata uyum sağlamasının en iyi yoludur (Bystrova, Widström, Matthiesen, Ransjö-Arvidson, WellesNyström, Wassberg ve Uvnäs-Moberg, 2003). Yeni doğanın beslenmesi sırasında anneden ya da bakım verenden aldığı taktil ve proprioseptif somatoduyusal uyaranlar dünyaya geldiği yeni 
çevresine uyum sağlamasını kolaylaştırır. Bunun yanı sıra taktil ve proprioseptif duyu bebeğin bakım veren yetişkine bağlanmasını, kendisini güvende hissetmesini sağlar. Gelişen güven bebeğin yaşamı boyunca çevresiyle kuracağı sosyal davranışların ve iletişimin temelini oluşturur (Schultz, 2013).

Dokunma gibi fiziksel temas, insan yaşamının tüm aşamalarında yer alır; ancak bebeklerin ve ebeveynlerinin yaşamları için özellikle merkezidir. Bebeklik dönemi boyunca bakım verenler, bebeklerine önemli dokunsal uyaranlar sağlar, çünkü dokunma günlük ebeveyn-bebek etkileşimlerinin ve ebeveynlik uygulamalarının çoğunda kullanılır. Kısa süreli anne-bebek etkileşimleri sırasında dahi birlikte geçirilen sürenin \% 55 ila \% 99'unda dokunma gerçekleşir. $\mathrm{Bu}$ nedenle, bebek ile bakıcısı arasındaki fiziksel temas, insan gelişiminin en önemli yönlerinden biridir (Mercuri ve vd., 2019).

Dokunsal duyumların, günlük yaşamdaki deneyimleri ve davranışları nasıl belirledikleri yaygın olarak bilinmektedir. Ancak dokunma yalnızca diş dünyayı algılamak, anlamak ve ona yanıt vermek için kullanılmamaktadır. Dış dünyadaki olaylar da aynı zamanda benlik ve vücut üzerinde etkiler bırakır. Bu nedenle, dokunma kendi bedenlerimizin zihinsel temsillerini ve diş çevreye göre mizacımızı çerçevelemede temel bir rol oynamaktadır (Bremner ve Spence, 2017).

Dokunsal sistem fiziksel, zihinsel ve duygusal insan davranışını belirlemede önemli bir rol oynar. Her birey, bebeklikten itibaren organize ve işlevsel olabilmek amacı ile dokunsal uyarıma ihtiyaç duyar. Merkezi sinir sistemindeki deri yoluyla algılanan duyuların verimsiz ya da işlevsiz olması durumu dokunsal işlevlerin bozukluğudur. Dokunmaya aşırı duyarlılığı olan çocuk (dokunsal savunuculuk) hafif dokunma duyumlarına olumsuz ya da duygusal olarak beklenmedik tepki verme eğiliminde olabilir. Çocuk bu şekilde sadece gerçek dokunuşa değil, aynı zamanda dokunulma beklentisine de tepki vermektedir. Çoğu dokunma hissini rahatsız edici ya da korkutucu algılayarak kavga, kaçma, korku hatta donma gibi tepkiler verebilmektedir. Çocuk dokunma duyumlarına aşırı ya da yetersiz yanıt verebilir. Bir dakika içinde, saçını taramak veya kucaklanmak gibi bir deneyimi gerçekten sevebilirken ve sonraki dakika içinde bu davranımlardan nefret edebilir. Biri koluna dokunduğunda alarm gibi bir çığlık atabilirken, vücudundaki kırık bir köprücük kemiğine kayıtsız kalabilir. Yatağa atlamayı sevebilirken, sırtının ovalanmasından nefret edebilir (Kranowitz, 2005).

Dokunma duyusu ile ilgili sorunlar yaşayan bireyler, vücudu ile ilgi algılarının yeterince gelişmemiş olması hareket etmeyi gerektiren becerilerden kaçınma ya da sosyal ortamlardan uzak durma ve benzeri davranışlar sergileyebilirler. Hareket gerektiren becerilerden kaçınmaları nedeniyle de kaba ve ince motor gelişimlerinde gecikmeler yaşayabilmektedir. $\mathrm{Bu}$ becerileri yeterince gelişmediği için oyuncak gibi nesneleri işlevlerine uygun olarak kullanmakta zorluk yaşayabilmektedirler (Herz ve Engen, 1996).

Wang, Hua ve $\mathrm{Xu},(2015)$ çalışmaları prenatal dönemde, düzenli nazik dokunsal uyarımların bebek mizacını etkileyeceğini gösterir. Düzenli dokunsal uyarım alan fetüsler doğumdan sonra izlendiğinde \% 73.7 kolay tip mizaçlı bebekler oldukları görülmüştür. Bu sonuçlar dokunsal hislerin, insanların davranışları ve duyguları üzerinde şaşırtıcı derecede güçlü etkileri olabileceğini göstermiştir. Özellikle dokunma, insanların uyumluluğunu değiştirebildiği görülmüştür. Prenatal dönemde olduğu kadar postnatal dönemde de dokunma önemli bir role sahiptir. Dokunma bebeklerde zamanla rahatlık, güvenlik, memnuniyet duyguları uyandıran fizyolojik ve psikolojik süreçlerle eşleşir. Özellikle sosyal dokunuş, pekiştirmeye dayalı öğrenmeye katkıda bulunur ve gelişim dönemlerini etkiler (Cascio, Moore ve McGlone, 2019). Ebeveyn dokunuşunun, çocukların sosyal tehdide yönelik örtük dikkat önyargısını azalttığ 1 ve sosyal açıdan endişeli çocukların tanıdık olmayan kişilere güveni artırdığı görülmüştür (Brummelman, Terburg, Smit, Bögels ve Bos, 2019). Bununla birlikte dokunma deneyiminin birinci elden yaşanmadığ durumlarda da etkileri olabileceğini göstermiştir. Dört aylık 
bebeklerin somatosensör kortekslerinin yalnızca kişisel dokunma deneyimi ile değil, aynı zamanda başkalarının deneyimlerini izleyerek de haritalama gerçekleştirebildikleri bilinmektedir (Rigato, Banissy, Romanska, Thomas, Velzen ve Bremner, 2019).

\subsection{Koku Duyu}

Koku alma (olfaksiyon), memeli gelişiminin ilk adımlarından itibaren algısal deneyimin kaçınılmaz kaynağıdır. Olfaksiyon nazal kemosensörler, anne-bebek ilişkisinin normal biyolojik işleyişinden kaynaklanan uyaranlarla doğrudan temas halindedir. Ana koku alma duyu nöronları, burun boşluğunun çatısı altında bulunur ve koku alma sinirleri yoluyla ana koku ampullerine bağlanır. Trigeminal sistemin dalları gibi üst solunum yolunu kaplayan epitelyumu innerve eder. Koku alma sistemi, gelen hava akışında düşük konsantrasyonlarda taşınan sayısız bileşiği algılayabilmektedir (Bremner ve Spence, 2017).

Koku alma sistemindeki nöral transdüksiyon diğer duyularda olmayan birkaç özellik ile karakterize edilir. Koku alma korteksi, limbik sistemde amigdala-hipokampal kompleksi ile doğrudan anatomik bir bağlantı oluşturur. Başka hiçbir duyu sistemi, duygu ve hafızanın nöral alt tabakaları ile bu tür doğrudan ve yoğun teması sağlayamamaktadır. Bu durum, koku ile uyandııılan hatıraların alışılmadık derecede duygusal olarak güçlü olmasını açıklayabilir. Bunun yanı sıra koku alma nöronları miyelinsizdir ve vücuttaki en yavaş iletim hızına sahiptirler. Bu nedenle de koku alma duyusu en yavaş duyu olabilmektedir. Görme duyusunda algılama yaklaşık 45 milisaniye, koku alma duyusu 400 milisaniye ve tanıma 600-800 milisaniye sürmektedir. Ancak bir kez koku algılandığında diğer duyuların ürettiği hislerden daha uzun süre devam eder. Koku alma reseptörleri, doğrudan çevreye maruz kalan tek nöronlardır ve aynı zamanda, yaklaşık olarak her 28 günde bir reseptörlerin tamamen değişmesiyle, yenilendiği bilinen tek nöron olmaları bakımından benzersizdirler (Isbell ve Isbell, 2007).

Prenetal dönemin beşinci haftası itibari ile gelişmeye başlayan ve on birinci hafta itibari ile burun epiteli oldukça gelişen fetüsün koku duyusu biyokimyasal gelişiminin tamamlanmasına bağlıdır. Erken dönemde başlayan biyokimyasal gelişim yaklaşık olarak gebeliğin 28 . haftasında tamamlanır (Slocombe, Carmichael ve Simner, 2016). Yeni doğan ile ilgili bilgiler yetersiz olsa da, bakım alma ve beslenme için kokuya koşullanmış olduklarını gösteren kanıtlar mevcuttur. Annenin göğüs kokusu, emzirilen bebeklerde emzirme deneyiminin bir işlevi olarak güvenilir bir pozitif baş yönelimi sağlar. Altı günlük olduklarında, bebekler başlarını güvenli bir şekilde annenin göğüs kokusuna yöneltebilirler (Bremner ve Spence, 2017). Küçük bir bebek, annesini kokuyla tanıyabilir, ancak çevredeki diğer kokuların çoğundan habersiz görünebilirler (Bloomfield, Alexander, Muelbert ve Beker, 2017).

Doğumdan sonraki ilk saatin yeni doğanların koku alma öğrenmesi için hassas bir dönem olduğuna dair kanıt görülmektedir. Doğumdan sonraki ilk saatlerde anne ve süt kokusuna maruz kalan bebeklerin kokuya yanıt vermesi, 2-3 günlük bir aralıkta bellekte izini tuttuklarını göstermektedir (Romantshik, Porter, Tillmann ve Varendi, 2007). Doğumdan sonraki ilk saatlerde annelerinin göğüsleri arasına yerleştirilen sağlıklı yeni doğan bebeklerin, meme ucunu yardım almadan buldukları ve genellikle doğumdan sonraki ilk saat içinde emmeye başladıkları görülmüştür. Yeni doğan 30 bebekten 23 'ünün kendi amniyotik sıvıları (AF) ile nemlendirilmiş meme arayarak buldukları görülmüştür. Amniyotik sıvı kokusuna yönelik gözlenen çekiciliğin, bebeklerin fetal dönemden itibaren koku duyusuna hassas olduklarını göstermektedir (Varendi, Porter ve Winberg, 1994).

\subsection{Tat Duyu}

İnsan dilinin yüzeyinde dört tür papilla (çıkıntı) vardır. Dildeki tat tomurcukları, epitel hücrelerinden oluşur ve ağız boşluğunun yanı sıra orofarenks ve girtlakta yer alır. Arka dilde 
daha güçlü algılanan acı tatlar, ön dilde daha güçlü olarak algılanan tuz ve tatlı tatlar ve dilin yan kenarlarında ekşi tatlar olarak algılanan bazı bölgesel farklılıklar mevcuttur (Mott ve Leopold, 1991). Tipik bir insan 20 ila 70 yaşları arasında, her bir çevresel papillada yaklaşık 250 tat tomurcuğuna ve yaprak papillalarında yaklaşık 1300 tat tomurcuğuna sahiptir. Tat tomurcuklarındaki hücrelerin ömrü oldukça kısadır ve sürekli olarak yenilenmeleri gerekir. Periyodik incelemeler tat tomurcuğunun içindeki hücrelerin yaklaşık 10 günlük bir yaşam süresine sahip olduğunu göstermiştir (Birnbaum, 2011).

Gıdalar sindirilirken, sistemler en diştan koku alma, tat ve trigeminal duyu beyin yapılarına duyusal bilgi sağlamak için eşzamanlı olarak çalışır. 'İçten koku alma' ve tat, özellikle yemek yeme veya içme söz konusu olduğunda genellikle eş zamanlı çalışır. Oro-nazal kemoreepsiyon, pasif ve aktif işbirliği sonucunda ortaya çıkan koku-tat algısal karışımlara neden olur (Bremner ve Spence, 2017).

Kimyasal tat duygusu, tatl1, ekşi, acı, tuzlu ve umami olmak üzere beş temel tat kategorisinin saptanmasını içerir. Tat alma molekülleri, ağızdaki tat reseptör hücrelerinin zarlarında bulunan ve tat tomurcukları şeklinde düzenlenen iyon kanallarına doğrudan veya dolaylı olarak bağlanır. Oradan, sinyal transdüksiyon olarak bilinen bir süreçle dönüştürülür ve beyne gönderilir. Maddeler çok nadiren saf tatlar halinde iletilir. Tüketimlerin çoğu yalnızca tadı değil; aynı zamanda doku, sicaklık, diğer dokunsal duyumlar, yanma ya da soğuma hissi gibi trigeminal sinir tahrişleri de eşlik eder. Bu nedenlerden dolayı lezzet algısı çok duyusaldır ve aynı zamanda koku alma ve görme gibi diğer duyulardan da etkiler gösterir (Slocombe, Carmichael ve Simner, 2016).

Koku alma ve tat alma işlevleri, somestezin başlangıcı ile kinestezinin başlangıcı arasında bir yerde işitme ve görmeden çok önce başlar. Tat tomurcukları gebeliğin 12. haftasına kadar erken bir zamanda bulunabilir ve morfolojik olarak gebeliğin 13. haftasına kadar olgunlaşır. $\mathrm{Bu}$ nedenle, insan nazal ve oral kemoreseptörleri, gebeliğin erken dönemlerinden itibaren duyusal işlevle uyumlu anatomik bir gelişim gösterir, ancak duyusal girdilerin algısal işlenmesi son üç aylık dönemde ortaya çıkmaktadır (Bremner ve Spence, 2017). Küçük miktarlarda amniyotik sıvının fetüs tarafindan yutulması ilk trimesterin sonunda başlar ve gebeliğin 34 . haftasında günde 750 ml'ye kadar ulaşır (Bystrova ve vd., 2003).

Koku ve tat duyuları, fetal yaşam sırasında gelişir ve doğum sonrası anneyi tanımadaki önemli rol oynar. Buna ek olarak, koku ve tat duyuları metabolik kontrolü teşvik eden etkiler de taşımaktadır (Bloomfield ve vd., 2017). Koku ve tat algısı, bağırsak hareketliliğini, insülin salgılanmasını, iştah, sindirim ve metabolik hormonların salgılanmasını artırdığı bilinmektedir. Prematüre bebeklerde sütün koku ve tadını alabilmeleri süt intoleransını iyileştirebildiği ve kilo artışı sağladığını göstermektedir (Goldstein, 2019).

\section{6. İşitme Duyu}

Yenidoğan bir bebeğin nasıl duyduğu ve işitmeyi nasıl gerçekleştirdiği merak konusudur. Eskiden bazı psikologlar yeni doğanların işlevsel olarak sağır olduğuna inanmışlardır. Fakat son zamanlarda yapılan birçok araştırma durumun böyle olmadığını kanıtlamıştır. Yapılan araştırmalar yeni doğanların işitsel bir kapasiteye sahip olduğunu ve bu kapasitenin çocuk büyüdükçe geliştiğini göstermiştir (Goldstein, 2019). De Casper ve Filter (1980) iki günlük bebeklerin, annelerinin seslerini duyabilmek için emme hızını düzenleyebildiklerini ve emme üzerinde kontrol sağladıklarını belirlemişılerdir. Bebeklere emme hızını ölçen besleyici olmayan bir emzik ve kulaklarına da verilen sesi dinleyebilmeleri için kulaklık takılmıştır. Bebeklere annelerinin sesi ve yabancı birinin sesi dinletilmiştir. Bebeklerin emme sırasında duraklamalarındaki farklılaşmalara bakıldığında, duraklamaların uzunluğu annelerinin sesini, kısalığı ise yabancı birinin sesini dinlediklerini göstermiştir. Sadece iki günlük bebeklerin bunu keşfetmeleri ve duraklamalarını annelerinin sesini duyacak şekilde ayarladıkları görülmüş ve 
anneleriyle yeterince vakit geçirmedikleri göz önüne alındığında bu sonuç; bebeklerde işitme algısının doğum öncesi dönemde geliştiği şeklinde yorumlanabilir.

İşitme duyusu doğum öncesi dönemde gelişmeye başlar. Gebeliğin altı-yedinci aylarında anne karnındaki bebek dışardan gelen yüksek seslere kol ve bacak hareketleriyle reaksiyon göstermektedir (Yükselen ve Aldiş, 2020). Bu nedenle doğum öncesi dönemde bebeklerin çeşitli kelimeleri ve sesleri duymasını sağlamaları için, annelerin bebekleriyle konuşmaları önerilmektedir (Güneş, 2010). Kisilevsky, Hains, Lee, Xie, Huang, Ye, Zhang ve Wang, (2003) yaptıkları bir çalışmada bebeklerin annelerinin sesini tanıyabilme yeteneklerini incelemişlerdir. Araştırmanın katılımcıları normal gebelik sürecini tamamlayan ve doğum öncesi bakım alan kadınlardır. Uygulama sırasında annelerin karnının $10 \mathrm{~cm}$ yukarısına bir hoparlör yerleştirilerek ve hoparlörün sesi $95 \mathrm{db}$ yüksekliğinde sese ayarlanmıştır. Bu hoparlörden bebeğin annesinin ve araştırma ekibi üyelerinden bir kadının okuduğu birer metin dinletilmiştir. Bebeğin annesinin sesini dinlerken kalp atış hızının annesinin sesine tepki olarak arttığı, yabacı bir kadının sesinin dinlerken de kalp atış hızının yabancı sese tepki olarak azaldığ 1 gözlenmiştir. Araştırma sonucu bebeklerin doğum öncesi dönemde işitme algısına ait deneyimlere sahip olduğunu göstermiştir.

Merkezi sinir sistemi sesin anlamlandırılması açısından önemlidir. İşitme ve duyma sesi alabilme yeteneğidir. Sesleri duymak ve anlamlandırmak aynı anlama gelmez. Sesler duyulsa bile anlamlandırılamayabilir (Çetin Sultanoğlu ve Aral, 2015). İşitsel algının gelişiminde işitsel konum belirleme ve işitsel düzenleme önemlidir. Işitsel konum belirleme; çevredeki her sesin bulunduğu ortamda işitsel bir alan oluşturması ve işitsel sistemin, işitsel alandan gelen sesleri görme ve duyma bilgilerini karşılaştırarak sesin geldiği konumu belirlemesi olarak açıklanabilir. İşitsel konum belirlemede iki kulağa gelen ipuçları önemlidir. Bu ipuçları kulaklar arası ses düzeyi farkı ve kulaklar arası zaman farkıdır. Bu süreçlerin her ikisi de sağ ve sol kulağa gelen ses sinyalinin karşılaştırılmasına dayanır. Işsitsel düzenleme ise; çoklu ses kaynaklarının düzenlenmesini içerir. Düzenlemenin yapılması için işitsel kaynakları ayırt etme ve işitsel ölçüyü algılama gereklidir (Goldstein, 2019).

\subsection{Görme Duyu}

Bebekler doğuştan gelen bir donanımla görme konusunda yetenekli olmalarına karşın, gözün bölümleri tam olarak gelişmediği için görme konusunda bazı sınırlılıklar vardır. Doğuştan gelen yetenek ve çevreden gelen etkileşimler sonucunda görme yeteneği hızla gelişir (Gander ve Gardiner, 2015). Yeni doğan bir bebek, kendi yüzünden $18 \mathrm{~cm}$ ile $40 \mathrm{~cm}$ uzaklıkta buluna bir nesneyi net bir şekilde görebilir. Bu uzaklığın ebeveynlerin bebeklerini kucakta tuttuğu sıradaki uzaklığa denk gelmesi tesadüf değildir. Bebeklerde görme yeteneği yaşamın birinci ayından itibaren hızlı bir şekilde gelişir ve bir yaş civarında yetişkin bir insanın görme seviyesine ulaşır (Trawick ve Smith, 2017).

Bebeklerin dünyayı tanımasına yardımcı önemli beceriler görsel tarama, görsel izleme ve derinlik algısıdır. Görsel tarama; bir cismin tüm özellikleri ile incelenerek cismin tamamını algılamasını içeren süreçtir. Bebekler üç aya kadar baktıkları cismin tamamını tarayabilecek yeterliliğe erişirler. Görsel izleme; bebeklerin hareket eden bir nesneyi takip etme yeteneğidir. Bebeklerde görsel izleme altı ay civarında daha iyi hale gelir (Trawick ve Smith, 2017). Derinlik algıs1; nesnelerin bireyden ve birbirinden uzaklığını kestirme yeteneğidir (Yükselen ve Aldiş, 2020). Bebeklerin hareket etmeye başlamasıyla birlikte gelişmeye başladığ belirtilmiştir (Trawick ve Smith, 2017). Derinlik algısını altı ay ve üzerindeki bebeklerde test eden Gibson ve Walk (1960) görsel uçurum deneyinde düz bir yüzey üzerinde illüzyon şeklinde oluşturulan ve derinlik algısı veren cam yüzeyde bebeklerin davranışlarını test etmiştir. Yüzeyin bir kısmı sı ğ ve güvenli görünürken, diğer kısmı ise uçurum hissi vermektedir. Uçurum hissi veren yüzeyin karşısında anneleri bebeklerini çağırmışlardır. Bebekler uçurum kısmına 
geldiklerinde yüzeyi elleriyle okşamış fakat geçmeyi reddetmişlerdir. Dobson ve Teller (1978) bebeklerde doğumdan sonraki ilk altı ayda görme keskinliğini çeşitli şekillerde ölçmüşlerdir. Yapılan ölçümler sonucunda görme keskinliğin ilk altı ayda giderek arttı̆̆ını belirlemişlerdir.

Goren, Sarty Wu (1975) yeni doğan bebeklerde görsel takip ve kalıp ayrımını yapabilme becerisini incelemiş̧lerdir. Araştırma sonucu bebeklerin diğer görsel uyaranlara kıyasla yüz modeline karşı duyarlılıklarının yüksek olduğunu ve erken yaşta görsel ayrımların yapıldığını göstermektedir. Testten önce gerçek bir yüz görmemiş bebeklerin uygun yüz uyaranını tercih etmesi, yeni doğan insanlarda yüzlere karşı öğrenilmemiş veya "gelişmiş" bir tepkinin mevcut olabileceğini düşündürmektedir. Frank, Vul ve Johnson (2009) bebeklerin, diğer nesnelere göre insan yüzüne bakma eğiliminin daha fazla olduğunu, insan yüzüne olan ilginin yaşla beraber giderek arttığını belirtmişlerdir. Gamé, Carchon ve Vital-Durand, (2003) bebeklerin yüz benzeri şekillere, diğer şekillere oranla daha fazla baktıklarını belirlemişlerdir. Bunun yanı sıra bebeklerin düz yüzeylere göre kontrast farkı olan siyah beyaz desenli yüzeylere daha fazla baktıkları belirlenmiştir (Fantz, 1963).

\section{DUYU BÜTÜNLEME}

Bireylerde duyuların aktif ve bütüncül bir şekilde kullanımını etkileyen birçok durumdan en belirgin olanı duyusal işlemleme becerisindeki bozukluktur ve bireylerin günlük yaşamsal aktivitelerini olumsuz olarak etkilemektedir (Birnbaum, 2011). Duyusal işlemleme eksikliği olan çocuklar giyinme, oyun oynama, yemek zamanı ve sosyal etkileşimler gibi günlük durumlara karşı tepkilerini düzenlemede dahi zorlanabilirler (Bloomfield ve vd., 2017). Duyusal bozukluk durumu "Otizm, DEHB (Dikkat Eksikliği Hiperaktivite Bozukluğu), Disklesi, Prematüre doğum, Serabral Palsi, William Sendromu, Şizofreni vb" rahatsızlıkları olan değişik yaş gruplarında sıklıkla görülebilmektedir (Beker, Opie, Noble, Jiang ve Bloomfield, 2017; DeCasper, Fifer, 1980).

Duyusal bütünleme, sinir sisteminin duyusal girdiyi eyleme nasıl entegre ettiğini açıklamaktadır. Kayıt ve modülasyon bozukluklarında iki yapı etkilenebilmektedir. Bunlar; limbik sistem ile vestibüler ve propriyoseptif sistemler. Vestibüler sistem, uzayda vücudun hareketinden meydana gelen duyusal bilgilerden sorumlu olan alandır. Proprioseptif sistemin ise, eklemler ve kaslar vasıtasıyla oluşan duyusal girdiyi işlemede görevi vardır (DeCasper ve Fifer, 1980). Bozulduğunda el çırpma davranışı gibi bozukluklara yol açabilir (Beker, Opie, Noble, Jiang ve Bloomfield, 2017). Ayres, bu sistemlerin bozukluğunu açıklarken dokunsal, hareket ve görsel uyaranların aşırı ya da az tepki şeklinde oluşmasının yerçekimsel güvensizlik, dokunsal savunmadan kaynaklı olduğunu söylemektedir. Ayrıca Ayres beyindeki bir alan olan amigdalanın duyusal kayıtta çok önemli yer kapladığını savunmuş ve son çalışmalarda bu görüşü destekler nitelikte olmuştur. Ayres'in duyusal kayıt ve vestibüler sistem ile ilgili görüşleri nöro bilimciler tarafindan beyin görüntüleme cihazlarıyla tespit edilmemiş olup bu görüş tam kanıtlanmış değildir (akt. Güneş, 2010).

Duyu bütünleme terapisi; doğru, adaptif ve işlevsel cevapları açığa çıkarmak maksadıyla, bireye göre planlanıp uygulanan özel programlar ve duyusal olarak zenginleștirilmiş interaktif eğlenceli oyun ve farklı etkinliklerden oluşan bir tedavi şeklidir. Tedavi şekli beynin yapısal veya fizyolojik değişikliklere uğrama yeteneği olarak ifade edilen nöroplastisite temel alınarak uygulanır. Tedavide beyin sapı seviyesinde işlenen zenginleştirilmiş duyusal ortam ve firsatların çocuklara uygun şekilde yapılandırılmış duyusal ve motor anlamda belirli zorluklar içeren etkinlikler düzenlenerek limbik sistem üzerinde çocuğun motivasyonunu uyarıp, çocuğu zorlayan (challenging) ve daha kompleks somatomotor adaptif yanttlar meydana çıkaran sensory-motor aktiviteler kullanılır. Bu aktiviteler "görsel, işitsel, taktil (dokunsal), vestibuler, proprioseptif, tat" duyuları uyaran, çocuğun ihtiyaçları doğrultusunda terapist tarafından düzenlenmektedir (Güneş, 2010). 
Duyusal bütünleme, esas olarak gelişimsel ve davranışsal bozuklukları olan çocuklar için bir müdahaledir. Duyusal bütünlemede yer alan aktiviteler vestibüler, propriyoseptif, işitsel ve dokunsal uyaranlar sağlar ve bu da duyusal sistemi düzenler. Bu tür uyaranlar, proprioseptif, dokunsal ve vestibüler zorlukları ortaya çıkarmak için kullanılan firçalar, salıncaklar, trambolinler, toplar ve diğer ekipmanlar kullanılarak oyunda sağlanır (Kisilevsky vd., 2003; Trawick ve Smith, 2017). Aktiviteler ayrıca uyarılma durumlarını güçlendirmek için derin bask1, eklem kompresyonu, oral ahlaki egzersizler ve vücut masajını içerebilir (Bloomfield vd., 2017). Duyusal bütünleme ve işlemleme etkinlikleri üzerine uluslararası literatürde birçok çalışmaya rastlanmıştır. Bu çalışmalardan bazıları incelendiğinde çıkan sonuçlar şu şekilde ifade edilmektedir.

Karim ve Mohammed (2015) çalışmasında otizmli çocuklar için bir duyusal bütünleştirme programı hazırlanmış ve uygulanan duyusal bütünleme programının otizmli çocuklar üzerinde olumlu etki yarattığı sonucuna ulaşmıştır. Yine benzer bir çalışma olan Sgandurra, Lorentzen, Inguaggiato, Bartalena, Beani, Cecchi ve CareToy Consortium, (2017) yaptığı çalışmada "Caretoy" müdehale programının standart müdahalelere göre duyusal eksiklik yaşayan bireyler üzerinde daha olumlu etki yarattığı sonucuna ulaşmışlardır.

Reynolds Glennon, Ausderau, Bendixen, Kuhaneck, Pfeiffer ve Bodison (2017) duyu bütünleme etkinlikleri için hangi yaklaşım seçilirse seçilsin müdahalelerin çocuk katılımına ve duyusal farklılıkları olan çocukların karmaşık ihtiyaçlarını karşılamak için çok yönlü bir yaklaşıma dayanması gerektiğini vurgulamaktadır. Ebeveynlerin durumunu inceleyen Complementary, Zimmer ve Desch (2012) ise çocukların duyusal temelli terapi teknikleri kullanılarak tedavi edilirken, ebeveynlerinin gelişimsel ve davranışsal problemler için bu teknikleri destekleyen sınırlı veriler konusunda eğitilmesi gerektiğini ifade etmişlerdir. DEHB bozukluğu olan bireyler için Lee ve Song (2015) tarafından yapılan çalışmada ise ağırlıklı bir yelek giyerek terapötik tırmanma aktiviteleri gerçekleştirmenin alfa dalgası aktivasyonunu ve çocuktaki dikkati geliştirdiğini söylemişlerdir.

Duyu bütünleme çalışmalarında propriyoseptif uyarı için; farklı fırçalarla uyarı vermek, pirinç, fasulye doldurulmuş kutulardan obje bulma çalışması, geniş tedavi topunu, itme karşılıklı itme veya duvara karşı itme, ağırlaştırılmış elbise, ceplerine ağırlık konmuş yelek giyme, derin basınç uygulama, eklem kompresyonu ve aproksimasyon(sıkıştırma) uygulama, geniş yastıklar ve minderlerle hamburger oyunu, trambolinde zıplama, salıncakta halat çekme, balon çıkartma oyunu, traş köpügü ile oynama ve ağır objeleri itme ve çekme etkinlikleri uygulanabilir. Taktil uyarı için; top havuzunda hareket, büyük yastıklarla çalışma, fasulye nohut doldurulmuş kutuda çalışma, farklı objeler doldurulmuş kutuda çalışmai farklı dokuda materyaller içeren oyuncaklar ile çalışmalar yapılabilir (Trawick ve Smith, 2017). Vestibular uyarı için; kaykay, salıncak, hamak, çanak, top, kaydırak, tambolin gibi araçları kullanarak yer çekimini, vücudunu farklı biçimlerde algılayabildiği çalışmalar yapılabilir (Gibson ve Walk, 1960; Yükselen ve Aldiş, 2020).

\section{DUYUSAL GELIŞ̧IMIN DESTEKLENMESİ}

Bebeğin anne karnında gelişimi oldukça hızlıdır. Anne karnındaki bu hızlı gelişim bebeğin dünyaya geldikten sonra hayatta kalabilmesi ve ortama uyum sağlaması için önemlidir. Bebeklik ve erken çocuklukta gelişim gösteren duyular bebeğin yeni tanıştığı çevreyi tanımasına yardımcı olan en temel araçtır. Bebekler doğduklarında tüm duyu organları tam olarak olgunlaşmasa da işlevseldir. Duyularını kullanarak çevresini tanımaya, benzer ve farklılıkları ayırt etmeye ve nesneler arasındaki ilişkiyi çözmeye çalışırlar. Duyular yardımıyla bebeklerin edindiği bu bilgiler onları yaşama hazırlar. Bu dönemde birçok görevi üstlenen ve bebeği yaşama hazırlayan duyuların etkin bir şekilde kullanılması için uygun uyarıcıların 
olmasına ihtiyaç vardır (Balat, Gül ve Öncü, 2005; MEB (Milli Eğitim Bakanlığı), 2013; Yükselen ve Aldiş, 2019). Bebeklik döneminde çevreden birden fazla duyuyu uyaracak ve duyular arasında uyarılmayı sağlayacak şekilde düzenlemeler yapılabilir. Duyular arasındaki uyarılma bebeğin öğrenmesini daha da hızlandıracaktır. Bu bağlamda bebeklerin gelişimi için zengin materyaller ile desteklenen duyusal deneyimler, hem duyu gelişimi hem de buna paralel olarak bilişsel-dil, motor, sosyal-duygusal gelişimlerini de katkı sağlayacaktır (Moyes, 2010; Koyuncuoğlu, 2017).

\subsection{Duyuların Gelişiminde Destekleyici Ortam}

Yaşamın ilk yıllarında çocukların gereksinim ve gelişim özelliklerine uygun, özgürce deneyimleyecekleri uygun ortam ile duyuların gelişimine için ihtiyaçları vardır. Özellikle bebek ve çocuğun yaşadığı ev ve eğitim kurumlarında duyuların gelişimi için onlara sunulacak çevredeki uyaranların birden fazla duyu etkileşiminin olabileceği şekilde planlanmasıyla sağlanabilir. Aktif öğrenme modelinde olduğu gibi bebeğin dokunarak, görerek, işiterek ve yaparak öğrendiği bir çevre ile öğrenme daha kalıcı olur. Ayrıca destekleyici ortam oluşturulurken güvenli bir ortamın sağlanması da bebek ve çocuk açısından oldukça önemlidir (Akça ve Bıçakçı, 2015; Berk, 2013; Keleş ve Çepni, 2006; Özata, 2015).

Ebeveyn ve eğitimciler, duyusal desteği sağlayabilmeleri için öncelikle bebeğin gelişiminde duyuların ne kadar önemli olduğunu bilmeleri gerekmektedir. Bebeğin görme, dokunma, tatma, işitme ve hareketten nasıl etkilendiğini iyice gözlemlemeliler. Böylece bebeğin duyusal deneyimleri incelenerek ona zengin çevre firsatları sunarak gelişime katkı sağlayabilirler. Her bebeğin ilgi ve ihtiyacı kendine özgüdür. Dolayısıyla her bebeğin duyusal girdilere verecekleri tepki de değişmektedir. Örneğin bazı bebekler öpülüp dokunulduğunda gülerek tepki verirken bazı bebeklerde ise tam tersi bir tepkide görülebilir. Bu noktada bebeğe sunulan farklı girdiler ile bebeğin reaksiyonları gözlemlenerek ortam düzenlemesi ona göre yapılabilir. Ortam düzenlemesi yapılmadan önce hangi durumların bebeği rahatlattığı ya da huzursuz ettiği bilinmelidir. Örneğin bebekler yüksek ses, aşırı parlak 1şıklar, keskin kokular ve ani dokunuşlardan rahatsız olurlar. Bu yüzden de uyarıcıları yerleştirirken bunlara dikkat etmek önemlidir. Bebeğin çevresindeki nesneler bebek tarafindan özgürce deneyimleyebilecekleri şekilde düzenlenmelidir. Ortamdaki duyusal uyaranlar bebeğin rahatlıkla ulaşabileceği yerlere konulmalıdır. Kısaca bebek için kendilerini rahat ve güvende hissedecekleri sakin bir ortam oluşturması önemlidir (Taygur Altıntaş ve Yılmazer, 2015). Bebeklik ve çocukluk döneminde duyuların gelişimini desteklemeye yönelik birçok çalışma yapılmıştır.

Yapılan çalışmalar incelendiğinde Yazıcı, Kandır ve Can Yaşar (2014) tarafından hazırlanan duyu eğitim programının yaratıcılık üzerine etkisini incelemek için 60-66 aylık çocuklara uygulanmıştır. Daha sonra duyu eğitim programının etkisi Yaratıcı Düşünme Resim Oluşturma Testi ile değerlendirilmiş ve çocukların yaratıcı düşünmeleri üzerinde programın olumlu etkisinin olduğu saptanmıştır. Robinson (2011)'nun bebeklik döneminde duyulara yönelik yaptığı çalışmada bebeğin ilk ve aktif olarak kullandığı duyunun dokunma duyusu olduğunu ortaya konulmuştur. Demirci (2010)'nin Görsel Algı Eğitiminin Beş-Altı Yaş Çocuklarının Görsel Alg1 Gelişimlerine Etkisi'nin incelendiği tez çalışmasında okul öncesi eğitim programının çocukların duyusal gelişimini desteklemeye yönelik görsel algı becerisinin gelişimini destekleyecek nitelikte etkinliklere yer verilmesi gerektiği ve okul ortamının duyusal gelişimde etkin rol oynadığı saptanmıştır.

\subsection{Duyuların Gelişiminde Duyu Materyalleri}

Bebekler duyuları yardımıyla çevreyi tanımaya çalışır. Bebeğin duyu gelişimini desteklemek için bebeğin gelişim düzeyine uygun materyaller kullanılır. Materyal kullanımı bebek ve çocuk için hem çevresini tanımasına hem de somut yaşantılar sayesinde öğrenmenin daha kalıcı olmasını sağlamış olur (Pekçetin, 2015). Yaşamın ilk yıllarında sağlıklı bir gelişim için bazen 
yapılandırılmış bazen de doğal bir öğrenme ortamına ve duyu materyallerine ihtiyaç vardır (Akça ve Bıçakçı, 2015). Ebeveyn ve eğitimciler duyuları desteklemek için bebeklerin ve çocukların gelişim düzeyi, ilgi ve ihtiyaçlarına uygun materyaller kullanabilirler. Çıngıraklar, sesli yapbozlar, tef, marakas, düdükler, sesli bloklar, el zili vb. materyaller kullanılarak işitme duyusu desteklenerek işitsel algılama düzeyi geliştirilebilir. Görme duyusu için farklı renkte minderler, geometrik şekiller, aynalar, kabartılmış renkli sütunlar, farklı renk ve şekillerde olan legolar, renkli kıyafetler, halı, perde, değişik renkte banyo lifleri vb. materyaller kullanılabilir. Tat ve koku duyusu için farklı kokuları olan oyuncaklar, kolonya, çiğnenebilen nesneler, vanilya, tarçın, ağız firçası, meyveler, sebzeler, üfleme topları vb. materyaller kullanılabilir. Burada özellikle dikkat edilmesi gereken nokta materyallerin gelişim düzeyine uygun olması ve zarar verecek kimyasallar barındırmamasıdır. Dokunma duyusu içinde uyun hamurları, dokunma tahtası, toprak havuzu, su havuzu, terapi firçaları, vakumlu toplar, el egzersizi topları vb. materyaller ile bebeğin ve çocuğun bedeni farklı materyaller yardımıyla uyarılması sağlanmış olur. Denge duyusunun gelişimi içinde zıplama tekeri, sağ-sol denge düzeneği, trambolin, kaykay, vücut çorapları, sepetli salıncak türünde materyaller kullanılabilir. Denge duyusu için kullanılan materyaller yardımıyla çocuğun dengede durabilmesi ve bedenini kontrol edebilmesi amaçlanır (Çetin Sultanoğlu ve Aral, 2015; MEB, 2013). Bebeğin kıyafetleri, oyuncakları, evdeki eşyalar, yiyecek ve içecekler aslında çevredeki birçok şey duyu gelişimi için değerlendirilebilir. Önemli olan materyallerin bebeğe ve çocuğa uygun olması özellikle de bebekler için tehlike içermeyen, onlara zarar vermeyen şekilde tasarlanmış olmasıdır. Diğer önemli bir husus da duyu materyallerin yetişkin gözetiminde kullanılmasıdır (Altıntaş ve Y1lmazer, 2015; MEB, 2013).

\section{SONUÇ VE ÖNERÍLER}

Bebeklerin ve çocukların denge ve hareket duyularının gelişimine yönelik duyusal deneyimler yaşamalarına firsat verilmelidir. Özgürce ve güvenli sürünme, emekleme, yürüme ve keşfetme fırsatı tanımak, farklı büyüklükteki nesnelerle oynama firsatı vermek, tırmanma, atlama, tekmeleme, yürüme gibi ihtiyaçlarını karşılayacakları ortam ve materyalleri sunmak çocukların vestibüler duyularının gelişimini destekleyecektir (Çöpkeş, 2013). Çocukların beden farkındalığı duyusunu desteklemek için kullanılacak materyaller çocuğun kendi bedeninin farkına varmasını sağlamalı, bedenini fiziksel çevresine uygun olarak hareket ettirebilmesi desteklenmeli ve kaza ya da tehlikeli durumlardan da çocuğu koruyup özgüvenini artırmak amaçlanmalıdır (Çetin Sultanoğlu ve Aral, 2015).

Duyusal olarak algılanan bilgilerin işlenmesi ve eyleme dönüştürülmesi noktasında sorun yaşayan bireylerin genel olarak herhangi bir özel durumunun olduğu göze çarpmaktadır. Bu tür bireylerin duyularını aktive etme ve duyularının organize çalışmasını kolaylaştıracak etkinlikler yapılarak bireylerin hem öğrenmelerini kolaylaştırıcı hem de günlük yaşamsal becerilerini kazanmada kolaylaştırıcı bir rol üstlenmektedir. Bu tür etkinlikler ise esas olarak tedavi niteliğinde mesleki terapistler tarafından yapılmaktadır. Ebeveynlerinde duyuların gelişimi konusunda hassas davranmaları ve doğum öncesinden başlayarak duyu gelişimini desteklemesi, çocukların duyusal gelişimi açısından önemlidir. Doğumdan hemen sonra başlayarak bebeklerin duyusal olarak desteklenmesi ve farklı uyaranların sunulması da bu süreci destekleyecektir. 


\section{KAYNAKÇA}

Akça, R. P. \& Bıçakçı, M. Y. (2015). Okul Öncesinde Materyal Geliştirme “Temel Konular”. Avcı N. (Ed.), Okul Öncesinde Materyal Geliştirme içinde (2 b. Cilt 8, 15-34). Ankara: Hedef Yayıncilik.

Aman, J. E., Elangovan, N., Yeh, I. L. \& Konczak, J. (2015). The effectiveness of proprioceptive training for improving motor function: A systematic review. Frontiers in Human Neuroscience, 8:1075:1-18. https://doi.org/10.3389/fnhum.2014.01075.

Angelaki, D. E. \& Cullen, K. E. (2008). Vestibular system: The many facets of a multimodal sense. Annual Review of Neuroscience, 31: 125-150 (https://doi.org/10.1146/annurev.neuro.31.060407.125555).

Arıhan, O. (2018). Vücut duyuları. İçinde: Foundations of Sensation and Perception, Canan S, Dokuyucu R. (Çev. Ed.) (2. Baskı) Ankara, Nobel Yayın, 60-84.

Armstrong, D. C., Redman-Bentley, D. \& Wardell, M. (2013). Differences in function among children with sensory processing disorders, physical disabilities and typical development. Pediatric Physical Therapy, 25(3), 315-321.

Balat, U. G., Gül, E. D. \& Öncü, E. Ç. (2005). Okul öncesi dönemde duyu eğitimi ve etkinlikler. İstanbul: Kare.

Balıkçı, A. (2013). Duyu bütünleme terapisinde çevresel düzenleme ve materyalin önemi. Ergoterapi ve Rehabilitasyon Dergisi, 1(2), 97-99.

Bar-Shalita, T., Vatine, J.J. \& Parush, S. (2008). Sensory modulation disorder: A risk factor for participation in daily life activities. Developmental Medicine \& Child Neurology, 50(12), 932-937.

Beker, F., Opie, G., Noble, E., Jiang, Y. \& Bloomfield, F. H. (2017). Smell and taste to improve nutrition in very preterm infants: A randomized controlled pilot trial. Neonatology, 111(3), 260-266.

Berk, L. E. (2013). Infants and children prenatal through middle chilhood. Işıkoğlu Erdoğan N. (Çev.) Doğum öncesinden orta çocukluğa bebekler ve çocuklar (7.bask1). Ankara: Nobel Akademik Yayıncilık.

Birnbaum, M. (2011). Season to taste: How ı lost my sense of smell and found my way. Granta Books.

Blecher, R., Heinemann, Y. L., Assaraf, E., Konstantin, N., Chapman, J. R., Cope, T. C., Bewick G. S., Banks, R. W. \& Zelzer, E. (2018). New functions for the proprioceptive system in skeletal biology. Philosophical Transactions, 373(1759), 20170327. (http://dx.doi.org/10.1098/rstb.2017.0327).

Bloomfield, F. H., Alexander, T., Muelbert, M. \& Beker, F. (2017). Smell and taste in the preterm infant. Early Human Development, 114, 31-34.

Bremner, A. J. \& Spence, C. (2017). The development of tactile perception. In Advances in Child Development and Behavior, (Vol. 52, pp. 227-268).

Brummelman, E., Terburg, D., Smit, M., Bögels, S. M. \& Bos, P. A. (2019). Parental touch reduces social vigilance in children. Developmental Cognitive Neuroscience, 35, 87-93.

Bystrova, K., Widström, A. M., Matthiesen, A. S., Ransjö-Arvidson, A. B., Welles-Nyström, B., Wassberg, C. \& Uvnäs-Moberg, K. (2003). Skin-to-skin contact may reduce negative consequences of "The stress of being born": A study on temperature in newborn infants, subjected to different ward routines in St. Petersburg. Acta Paediatrica, 92(3), 320-326.

Cabral, T. I., Silva, L. G. P., Tudella, E. \& Martinez, C. M. S. (2015). Motor development and sensory processing: A comparative study between preterm and term infants. Research in Developmental Disabilities, 36: 102-7.

Cascio, C. J., Moore, D. \& McGlone, F. (2019). Social touch and human development. Developmental Cognitive Neuroscience, 35, 5-11. 
Castiello, U., Becchio, C., Zoia, S., Nelini, C., Sartori, L., Blason, L. \& Gallese, V. (2010). Wired to be social: The ontogeny of human interaction. Plos One, 5(10), e13199.

Chinn, L. K., Hoffmann, M., Leed, J. E. \& Lockman, J. J. (2019). Reaching with one arm to the other: Coordinating touch, proprioception, and action during infancy. Journal of Experimental Child Psychology, 19-32. https://doi.org/10.1016/j.jecp.2019.01.014.

Christina, L., Stephen, R., Douglas, J. W., Eileen, P., Julia, E. L., Podolak, O. E. \& Grady, M. F. (2018). Vision and vestibular system dysfunction predicts prolonged concussion recovery in children. Clinical Journal of Sport Medicine, 28(2):139-145 (doi: 10.1097/JSM.0000000000000507).

Complementary, S. O., Zimmer, M. \& Desch, L. (2012). Sensory integration therapies for children with developmental and behavioral disorders. Pediatrics, 129(6), 1186-1189.

Cutfield, N. J., Scott, G., Waldman, A. D., Sharp, D. J. \& Bronstein, A. M. (2014). Visual and proprioceptive interaction in patients with bilateral vestibular loss. NeuroImage: Clinical, 4: 274-282 (https://doi.org/10.1016/j.nicl.2013.12.013).

Çelik, H. İ., Elbasan, B., Gücüyener, K., Kayıhan, H. \& Huri, M. (2018). Preterm ve term bebeklerde duyusal işlemleme becerisinin incelenmesi. Fizyoterapi Rehabilitasyon, 29(2):31-36. (doi: 10.21653/tjpr.343255).

Çetin, Sultanoğlu, S. \& Aral, N. (2015). Duyuların gelişimi. Yıldız Bıçakçı M. (Ed.), Bebeklik ve ilk çocukluk döneminde (0-36 ay) gelişim duyuların gelişimi ve desteklenmesi içinde (205-222). Ankara: Eğiten Kitap Yayınevi.

Çöpkes, Ü. (2013). Otistik çocuklarda vestibüler rehabilitasyonun etkisi. (Yüksek Lisans Tezi) İstanbul Bilim Üniversitesi, İstanbul.

De Casper, A. J. \& Fifer, W. P. (1980). Of human bonding: Newborns prefer their mothers' voices. Science Issue 4448, pp. 1174-1176. DOI: 10.1126/science.7375928

Demirci, A. (2010). Görsel algı eğitiminin beş-altı yaş çocuklarının görsel algl gelişimlerine etkisi. (Doktora tezi) Gazi Üniversitesi, Ankara.

Dobson, V. \& Teller, D. Y. (1978). Visual acuity in human infants: A review and comparison of behavioral and electrophysiological studies. Vision Research, 18(11), 1469-1483.

Dunn, W. (2001). The sensations of everyday life: Empirical, theoretical, and pragmatic considerations. American Journal of Occupational Therapy, 1;55(6):608-20.

Fantz, R. L. (1963). Pattern vision in newborn infants. Science, 140(Whole No. 3564), 296297. https://doi.org/10.1126/science.140.3564.296.

Fırat, B. (2019). Yaşlılarda ayak taban duyu eğitiminin sensorimotor organizasyona etkisinin incelenmesi. (Doktora Tezi) Hacettepe Üniversitesi, Ankara.

Fidan, U., Yıldız, M. \& Şahan, A. (2019). İnsan bilgisayar etkileşimi ile proprioseptif duyuların geliştirilmesi. Avrupa Bilim ve Teknoloji Dergisi, (Özel Say1):177-184.

Frank, M. C., Vul, E. \& Johnson, S. P. (2009). Development of infants' attention to faces during the first year. Cognition, Vol:110(2),160-170.

Gamé, F., Carchon, I. \& Vital-Durand, F. (2003). The effect of stimulus attractiveness on visual tracking in 2- to 6-month-old infants. Infant Behavior \& Development, 26: 135150 .

Gander, M. J. \& Gardiner, H. W. (2015). Çocuk ve Ergen Gelişimi. Onur, B. (Çev. Ed.) (8.Bask1) Ankara: İmge Kitapevi.

Gibson, E. J. \& Walk, R. D. (1960). The "visual cliff". Scientific American. 202: 64 -71.

Goble, D. J., Lewis, C. A., Hurvitz, E. A. \& Brown, S. H. (2005). Development of upper limb proprioceptive accuracy in children and adolescents. Human Movement Science. 24 (2): 155-170 (https://doi.org/10.1016/j.humov.2005.05.004).

Goldstein, E. B. (2019). Sensation and perception. Malkoç G. \& Kardeş FG. (Çev. Ed.) Duyum ve alg1 (9. Baskı). Ankara: Nobel Akademik Yayıncılık. 
Golz, A., Netzer, A., Yeger, B. A., Westerman, S. T., Gilbert, L. M. \& Joachims, H. Z. (1998). Effects of middle ear effusion on the vestibular system in children. Otolaryngol Head Neck Surg. 119 (6):695-9 (doi: 10.1016/S0194-5998(98)70039-7).

Goren, C. C., Sarty, M. \& Wu, P. (1975). Visual following and pattern discrimination of facelike stimuli by newborn infants. Pediatrics. 56:544-545.

Güneş, F. (2010). Ninnilerin çocukların dil ve zihinsel gelişimine etkisi. Journal of World of Turks, 2(3): 27-38.

Herz, R. S. \& Engen, T. (1996). Odor memory: Review and analysis. Psychonomic Bulletin \& Review, 3(3), 300-313.

Hoeve, J. (2020). Clinical evidence of vestibular dysregulation in colicky babies before and after chiropractic treatment versus non-colicky babies. Research Artıcle.1-13. DOI: 10.21203/rs.3.rs-117516/v1.

Isbell, C. \& Isbell, R. (2007). Sensory integration: A guide for preschool teachers. Gryphon House.

Karim, A. E. A. \& Mohammed, A. H. (2015). The effectiveness of the sensory integration program in motor skills in children with autism. Egyptian Journal of Medical Human Genetics, 16 (4), 375-380.

Kaynak, H., Altun, M., Özer, M. \& Akseki, D. (2015). Sporda propriosepsiyon ve sıcak - soğuk uygulamalarla ilişkisi. CBÜ Beden Eğitimi ve Spor Bilimleri Dergisi. 10(1): 10-35.

Keleş, E. \& Çepni, S. (2006). Beyin ve öğrenme. Türk Fen Ĕ̆itim Dergisi, 3(2), 66-82.

Kesavan, K., Frank P., Cordero, D. M., Benharash, P. \& Harper, R. M. (2016). Neuromodulation of limb proprioceptive afferents decreases apnea of prematurity and accompanying intermittent hypoxia and bradycardia. Plos One, 11(6):1-16. e0157349. doi:10.1371/journal.pone.0157349.

Kisilevsky, B. S., Hains, S. M., Lee, K., Xie, X., Huang, H., Ye, H. H., Zhang, K., Wang, Z. (2003). Effects of experience on fetal voice recognition. Psychological science, 14(3), 220-224.

Koyuncuoğlu, B. (2017). Anasınıfina devam eden dört beş yaş çocukların yaratıcı düşünme becerilerine duyu eğitim programının etkililiğinin incelenmesi. (Doktora Tezi) Hacettepe Üniversitesi, Ankara.

Kranowitz, C. S. (2005). The out-of-sync child: Recognizing and coping with sensory processing disorder. Penguin. (80-101)

Lahunta, A. \& Glass, E. (2009). Vestibular system special proprioception. Veterinary Neuroanatomy and Clinical Neurology, 319-347 (doi: 10.1016/B978-0-7216-67065.00012-3).

Lee, H. S. \& Song, C. S. (2015). Effects of therapeutic climbing activities wearing a weighted vest on a child with attention deficit hyperactivity disorder: A case study. Journal of Physical Therapy Science, 27(10), 3337-3339. doi:10.1589/jpts.27.3337

Magalhães, L. C. (2008). Integrac,ão sensorial: Uma abordagem especi'fica da Terapia Ocupacional. In A. F. Drumond \& M. B. Rezende (Eds.), Intervenc, ões da terapia ocupacional içinde (45-69). Belo horizonte: Ed. UFMG.

Martens, S., Dhooge, I., Dhondt, C., Leyssens, L., Sucaet, M., Vanaudenaerde, S., Rombaut, L. \& Maes L. (2019). Vestibular infant screening - flanders: The implementation of a standard vestibular screening protocol for hearing-impaired children in Flanders. International Journal of Pediatric Otorhinolaryngology, 120:196-201.

Mather, G. (2018). Foundations of sensation and perception. Canan S. \& Dokuyucu R. (Çev.) Duyu ve algının temelleri. Ankara: Nobel Akademik Yayınc1lık.

MEB. (2013). 0-36 Ay çocukları için eğitim programı ile bütünleştirilmiş aile destek rehberi aile kitabı (EBADER) Ankara: MEB. 
Mercuri, M., Stack, D. M., Trojan, S., Giusti, L., Morandi, F., Mantis, I. \& Montirosso, R. (2019). Mothers' and fathers' early tactile contact behaviors during triadic and dyadic parent-infant interactions immediately after birth and at 3-months postpartum: Implications for early care behaviors and intervention. Infant Behavior and Development, 57, 101347.

Miller, L. J., Anzalone, M. E., Lane, S. J., Cermak, S. A. \& Osten, E. T. (2007). Concept evolution in sensory integration: A proposed nosology for diagnosis. American Journal of Occupational Therapy, 61(2), 135-140.

Mott, A. E. \& Leopold, D. A. (1991). Disorders in taste and smell. Medical Clinics of North America, 75(6), 1321-1353.

Moyes, R. (2010). Building sensory friendly classrooms to support children with challenging behaviours, Texas: Sensoryworl.

Özakın, S. (2018). Otizm spektrum bozukluğu olan çocuklarda duyu bütünleme eğitiminin proprioseptif duyu, motor performans ve duyu profili üzerine etkisi. (Yüksek Lisans Tezi) Doğu Akdeniz Üniversitesi, Kuzey Kıbrıs.

Özata, S.C. (2015). Okul öncesinde oyun temelli duyu eğitimi. Ankara: Nobel Yayınc1lık.

Pekçetin, S. (2015). Prematüre bebeklerde duyu bütünleme müdahale programının duyusal işlemleme, emosyonel ve adaptif cevaplar üzerine etkisi. (Doktora tezi) Hacettepe Üniversitesi, Ankara.

Proske, U. \& Gandevia, S. C. (2012). The proprioceptive senses: Their roles in signaling body shape, body position and movement, and muscle force. Physiological Review, 92: 16511697. (doi:10.1152/physrev.00048.2011).

Reynolds, S., Glennon, T. J., Ausderau, K., Bendixen, R. M., Kuhaneck, H. M., Pfeiffer, B. \& Bodison, S. C. (2017). Using a multifaceted approach to working with children who have differences in sensory processing and integration. American Journal of Occupational Therapy, 71(2), 7102360010p1-7102360010p10.

Rigato, S., Banissy, M. J., Romanska, A., Thomas, R., Van Velzen, J. \& Bremner, A. J. (2019). Cortical signatures of vicarious tactile experience in four-month-old infants. Developmental Cognitive Neuroscience, 35, 75-80.

Rine, R. M. \& Wiener-Vacher, S. (2013). Evaluation and treatment of vestibular dysfunction in children. Neuro Rehabilitation, 32(3), 507-518, (doi: 10.3233/NRE-130873).

Robinson, M. (2011). Understanding behaviour and development in early childhood a guide to theory and practice. New York: Routledge \& CRC Press.

Romantshik, O., Porter, R. H., Tillmann, V. \& Varendi, H. (2007). Preliminary evidence of a sensitive period for olfactory learning by human newborns. Acta Paediatrica, 96(3), 372376.

Schaaf, R. C. \& Miller, L. J. (2005). Occupational therapy using a sensory integrative approach for children with developmental disabilities. Mental Retardation and Developmental Disabilities Research Reviews, 11(2):143-8.

Schultz, A. H. (2013). Some factors influencing the social life of primates in general and o1" early man in particular. Social Life of Early Man, 16, 58.

Sgandurra, G., Lorentzen, J., Inguaggiato, E., Bartalena, L., Beani, E., Cecchi, F., Dario, P., Giampietri, M., Greisen G., Herskind, A., Nielsen, J. B., Rossi, G. \& Cioni, G. (2017). A randomized clinical trial in preterm infants on the effects of a home-based early intervention with the 'CareToy System'. Plos One, 12(3), e 0173521.

Sidar, E. A. \& Öztop, D. B. (2017). Duyu bütünleme terapisi. Türkiye Klinikleri Çocuk Psikiyatrisi-Özel Konular, 3(2), 153-162.

Slocombe, B. G., Carmichael, D. A. \& Simner, J. (2016). Cross-modal tactile-taste interactions in food evaluations. Neuropsychologia, 88, 58-64. 
Şeker, F.S. (2019). Entelektüel yetersizliği olan çocuklarda hareket ĕgitiminin denge becerilerine etkisi. (Doktora tezi) Celal Bayar Üniversitesi, Manisa.

Taygur, Altıntaş, T. \& Yılmazer, Y. (2015). Bebeklik ve ilk çocukluk döneminde (0-36 Ay) gelişsim duyuların gelişimi ve desteklenmesi. Yıldız Bıçakçı M. (Ed.), Duyuların gelişimi ve desteklenmesi içinde (305-338). Ankara: Eğiten Kitap Yayınevi.

Trawick-Smith, J. (2017). Early childhood development. Akman B. (Çev.) Erken çocukluk döneminde gelişim. Ankara: Nobel Akademik Yayıncılık.

Turhan, A. (2018). Spastik diplejik serebral palsili çocuklarda duyu bütünleme programı ile konvansiyonel egzersiz tedavisinin; Spastisite, denge ve motor fonksiyona etkisi. (Yüksek lisans tezi) Haliç Üniversitesi, İstanbul.

Varendi, H., Porter, R. H. \& Winberg, J. (1994). Does the newborn baby find the nipple by smell? The Lancet, 344(8928), 989-990.

Wang, Z. W., Hua, J. \& Xu, Y. H. (2015). The relationship between gentle tactile stimulation on the fetus and its temperament 3 months after birth. Behavioural Neurology. (https://doi.org/10.1155/2015/371906)

Yazıcı, E., Kandır, A. \& Can, Yaşar M. (2014). Duyu eğitimi programının çocukların yaratıcı düşünme becerilerine etkisi. Akad Bakış Dergisi. (www.akademikbakis.org)

Yükselen, A. \& Aldiş, B. (2020). Duyusal gelişim. Aral, N., Temel, Z. F. (Ed.), Çocuk gelişimi içinde (94-111) Ankara: Hedef yayıncılık. 